\title{
Pattern of femoro-popliteal aneurysms in an African population
}

\section{Padrão de aneurismas femoro-poplíteos em uma população africana}

\author{
Julius A Ogeng'o, Beda O Olabu*
}

\begin{abstract}
Objective: To describe the pattern of femoro-popliteal aneurysms in an African Kenyan population.

Patients and methods: Records of African in-patients with diagnosis of femoral or popliteal aneurysms admitted at the Kenyatta National Hospital, Nairobi, Kenya, from January 1998 to December 2007 were examined for presentation, diagnosis, risk/comorbid factors, site, age, and gender distribution. Data were analyzed using SPSS 13.0 and presented using tables.

Results: Femoro-popliteal aneurysms constitute 33 out of 96 of peripheral cases (34.4\%). The most common presentations were pulsatile mass (48.5\%) and pain and swelling (33.3\%). Pain alone and bleeding occurred in 9.1\% each. Diagnosis was performed through Doppler ultrasound (45.5\%), angiography (30.3\%) and ultrasonography (24.3\%). Aneurysms were associated with trauma (51.5\%), atherosclerosis (21.2\%), smoking (9.1\%) and hypertension (6.1\%). Site distribution was common femoral (33.3\%), superficial femoral (36.4\%) and popliteal (30.3\%). Mean age was 46 years (range 13-79 years); with 20 (60.6\%) of them occurring in individuals aged 50 years and younger. Male:female ratio was 15:1.

Conclusion: In the present study, femoro-popliteal aneurysms constituted less than $40 \%$ of peripheral aneurysms, and superficial femoral artery was the most common site. They occurred predominantly in males aged 50 years and younger and were associated mainly with trauma and atherosclerosis. Prevalence, site and age distribution of these aneurysms in the Kenyan population differs from that described in studies of Caucasian populations.
\end{abstract}

Keywords: Aneurysm, femoral artery, popliteal artery.

\section{Resumo}

Objetivo: Descrever o padrão de aneurismas femoro-poplíteos em uma população africana do Quênia.

Pacientes e Métodos: Prontuários de pacientes africanos internados com o diagnóstico de aneurisma femoro-poplíteo no Hospital Kenyatta, Nairóbi, Quênia, de janeiro de 1998 a dezembro de 2007 foram examinados quanto a apresentação, diagnóstico, fatores de risco/comorbidades, local, idade e gênero. Os dados foram analisados usando o Program SPSS 11.50 e apresentados em tabelas.

Resultados: Aneurismas femoro-poplíteos constituem 33 dos 96 casos de aneurisma periférico (34,4\%). As apresentações mais comuns foram massa pulsátil (48,5\%) e dor e inchaço (33,3\%). Dor isolada e sangramento ocorreram em 9,1\% cada. O diagnóstico foi feito por ultrassonografia Doppler (45,5\%), angiografia (30,3\%) e ultrassonografia simples (24,5\%). Aneurismas foram associados a trauma (51,5\%), aterosclerose (21,2\%), tabagismo (9,1\%) e hipertensão arterial (6,1\%). A distribuição por locais foi femoral comum (33,3\%), femoral superficial (36,4\%) e poplítea (30,3\%). A média de idade foi de 46 anos (variando de 13 a 79 anos), com 20 casos (60,6\%) ocorrendo em indivíduos com 50 anos de idade ou menos. A relação masculino:feminino foi de 15:1.

Conclusão: No presente estudo, aneurismas femoro-poplíteos constituíram menos de $40 \%$ dos aneurismas periféricos, e a artéria femoral superficial foi o local mais comum. Eles ocorreram predominantemente em homens com idade igual ou menor que 50 anos e foram associados principalmente a trauma e aterosclerose. A prevalência, local e distribuição destes aneurismas diferem das descritas nas populações brancas.

Palavras-chave: Aneurisma, artéria femoral, artéria poplítea.

\section{Introduction}

Femoro-popliteal aneurysms are rare if compared to aortic ones, but they are important because of their thromboembolic or rupture potential and their predictive value for existence of aortic and other extra-aortic aneurysms. ${ }^{1,2}$ Their site, age and gender distribution display ethnic ${ }^{3}$ and regional ${ }^{1}$ variations. In Africa, as atherosclerosis becomes an important disease, its sequelae, including aneurysms, may become increasingly evident. ${ }^{4}$ Furthermore, there has been recent concern that the number of patients at risk of femoral artery pseudoaneurysm may be increasing in parallel with the extent of intravenous

*Department of Human Anatomy, University of Nairobi, Nairobi, Kenya 
drug abuse and the number of cardiac vascular radiological interventional procedures performed each year. ${ }^{5}$ Nonetheless, reports of femoro-popliteal aneurysms from Africa, including Kenya, are scarce. Data on pattern of aneurysms are important in formulation of prevention and management strategies. This study reports the distribution of femoro-popliteal aneurysms in an African Kenyan population.

\section{Patients and Methods}

This was a retrospective cross-sectional study conducted at Kenyatta National Hospital in Nairobi, Kenya, a sub-Saharan African country on the East coast. $\mathrm{KNH}$ is a referral and teaching hospital with 80 cardiovascular beds, 8 cardiovascular surgeons and a total in-patient turnover of 80,000 patients per year. The patients are predominantly low to middle class African natives. Ethical approval was obtained from Kenyatta National Hospital-Ethics and Research Committee (KNH-ERC/01/404). Records of African Kenyan patients seen in the hospital over a ten year period from January 1998 to December 2007 with diagnosis of femoral or popliteal aneurysm at discharge or death were examined for presentation, diagnosis, predisposing factors, site, age and gender distribution. Only patients with complete records were included. Those whose records were incomplete or with unconfirmed diagnosis were excluded. The records were divided into those for male and female, and each gender divided into eight age groups, namely $0-10$; 11-20, 21-30; 31-40; 41-50; 51-60; 61-70; $\geq 71$ years.

Table 1 - Risk/comorbid factors associated with femoro-popliteal aneurysms

\begin{tabular}{lc}
\hline Risk/comorbid factor & Frequency (\%) \\
\hline Trauma & $17(51.5)$ \\
Atherosclerosis & $7(21.2)$ \\
Smoking & $3(9.1)$ \\
Hypertension & $2(6.1)$ \\
Infection & $2(6.1)$ \\
No factor identified & $2(6.1)$ \\
Total & $33(100)$ \\
\hline
\end{tabular}

Table 2 - Age distribution of femoro-popliteal aneurysms

\begin{tabular}{|c|c|c|c|c|}
\hline \multirow[t]{2}{*}{ Age (years) } & \multicolumn{3}{|c|}{ Specific site of femoro-popliteal aneurysm } & \multirow{2}{*}{$\begin{array}{c}\text { Totals } \\
\text { Counts (\%) }\end{array}$} \\
\hline & Superficial femoral & Common femoral & Popliteal & \\
\hline $21-30$ & 3 & 3 & 2 & $8(24.2)$ \\
\hline $31-40$ & 4 & 0 & 1 & $5(15.2)$ \\
\hline $41-50$ & 3 & 3 & 1 & $7(21.2)$ \\
\hline $51-60$ & 0 & 2 & 5 & $7(21.2)$ \\
\hline $61-70$ & 2 & 0 & 1 & $3(9.1)$ \\
\hline $71-80$ & 0 & 3 & 0 & $3(9.1)$ \\
\hline Totals & 12 & 11 & 10 & $33(100)$ \\
\hline Percentages & 36.4 & 33.3 & 30.3 & 100 \\
\hline
\end{tabular}

The aneurysms were divided into popliteal, common, superficial and deep femoral. Data were analyzed using SPSS 13.0 (IBM, Chicago) and presented using frequency tables.

\section{Results}

Femoro-popliteal aneurysms constitute 33 of the 96 peripheral cases $(34.4 \%)$. The most common presentation was pulsatile mass $(48.5 \%)$ followed by pain and swelling (33.3\%). Pain and bleeding constituted 9.1\% each. Diagnosis was confirmed by Doppler ultrasound (45.5\%), angiography (30.3\%) and ultrasonography (24.2\%). The most common site was superficial femoral artery $(36.4 \% ; \mathrm{N}=12)$ followed by common femoral artery $(33.3 \% ; \mathrm{N}=11)$ then the popliteal artery $(30.3 \% ; \mathrm{N}=10)$. The most prevalent risk factors were trauma (51.5\%), atherosclerosis (21.1\%), smoking (9.1\%), hypertension $(6.1 \%)$ and infection (6.1\%). In 2 cases $(6.1 \%)$ no factor was identified (Table 1$)$. Implicated causes of trauma were fracture femur (8), blunt trauma (3), catheterization (3) and surgery (3). Atherosclerosis was confirmed in 7 cases (21.2\%), 4 of which were in the common femoral artery, and 3 in the popliteal artery. The mean age was 46 years (range 13-79 years). Most commonly affected age group was 41-60 years and over $60 \%$ of the individuals were aged 50 years and below (Table 2). The male:female ratio was 15.5:1 with no common femoral artery aneurysm in females (Table 3 ).

\section{Discussion}

In most series from Western countries with predominantly Caucasian populations, femoro-popliteal aneurysms comprise $70-85 \%$ of peripheral aneurysms. ${ }^{1,6}$ Observations of the present study, showing that they constitute only $34.4 \%$, suggest that peripheral aneurysms in the studied population are more widespread. Distribution of peripheral aneurysms varies with ethnicity, ${ }^{3}$ age and etiology ${ }^{6,7}$ The involvement of diverse arteries implied in this study suggests a unique profile of risk factors in the population.

\section{Site distribution}

There are few studies on combined femoral and popliteal artery aneurysms. ${ }^{1,6}$ Most studies, mainly case reports,

Table 3 - Gender distribution of femoropopliteal aneurysms

\begin{tabular}{lccc}
\hline Specific site of femoropopliteal aneurysm & Male & Female & Total \\
\hline Common femoral & 12 & 0 & 12 \\
Superficial femoral & 10 & 1 & 11 \\
Popliteal & 9 & 1 & 10 \\
Total & 31 & 2 & 33 \\
\hline
\end{tabular}


are on either artery separately. ${ }^{2,8}$ This has rendered comparison difficult. Nonetheless, the popliteal artery is reported to be the most common site of extra-aortic aneurysms in predominantly Caucasian populations. ${ }^{1,6,8,9}$ Observations of the present study reveal, at variance with this conventional view, that popliteal artery aneurysms account for only just over $10 \%$ of peripheral aneurysms. This implies interpopulation variations in the prevalence of these aneurysms, probably dependent on a combination of environmental and genetic factors. ${ }^{8,10,11}$ In the present study, like in the Japanese one, ${ }^{12}$ femoral artery was more affected than the popliteal, further supporting the suggestion that the localization of femoro-popliteal aneurysms varies between populations. $^{6,7}$

Femoral artery aneurysms are rare but usually rated second to popliteal ones., ${ }^{2,9,10,13}$ Of these, the common femoral artery is the most frequently affected segment, predominantly due to stress and kinking resulting from repeated hip flexion. ${ }^{1}$ The rarity of superficial femoral artery aneurysms is attributed to the muscle support and minimal bending stress enjoyed by this artery. ${ }^{13}$ Observations of the present study that the superficial femoral artery is more affected than the common femoral suggest that other etiological factors are involved. Other studies reported that most femoral artery aneurysms are pseudoaneurysms caused by trauma, catheterization, intravenous injection of drugs, anastomotic leakage or infection., ${ }^{5,13,14}$ Indeed the superficial femoral artery is a frequent site of vascular injury. ${ }^{15}$ Accordingly, it is likely that the predominance of superficial femoral artery in the present study is due to the high frequency of trauma observed, and that most of them are pseudoaneurysms. Pertinent to this suggestion is the observation that pulsatile mass and pain, usually ascribed to pseudoaneurysms, ${ }^{16}$ were the predominant presenting features.

\section{Risk factor and comorbidities}

Most studies reported true and false aneurysms separately, complicating comparison of risk factor prevalences. For true femoro-popliteal aneurysms, however, atherosclerosis is the most common risk factor in Caucasian populations. ${ }^{8,17}$ In the present study, atherosclerosis constituted over $20 \%$ of identifiable risk factors. This implies that, as in another African state, ${ }^{4}$ this disease is a substantial cause of morbidity in the black Kenyan population. Control of cardiovascular risk factors such as hypertension and smoking observed in the present study may contribute to reducing the incidence of these aneurysms.
Trauma has been implicated in most pseudoaneurysms. ${ }^{5,14,15}$ Observations of the current study reveal that trauma, notably from femoral fractures, catheterization and surgery was the most frequent risk factor. This implies that due diligence should be exercised in the management of fractures and during catheterization or surgery in the vicinity of the artery to reduce the incidence of pseudoaneurysms.

Other cases of aneurysms may be caused by infections, ${ }^{7}$ as observed in the current study. This suggests that in the black Kenyan population non communicable diseases coexist with infectious conditions, supporting reports that Africa is undergoing an epidemiological transition.

\section{Age and gender distribution}

Observations of the current study reveal a mean age of 46 years. This is significantly lower than the widely reported age range of $70-80$ years. ${ }^{1,10,18}$ The observations that over $60 \%$ of the patients are aged 50 years and below, however, corroborate Kitchen's view that among Africans, aneurysms occur in younger people $\mathrm{e}^{3}$ and are also concordant with the observation that most of the cases in this study are non-atherosclerotic, being associated more with trauma and, in a few cases, infections. Indeed atherosclerotic aneurysms occur in older people while traumatic and genetic ones occur in younger individuals. ${ }^{819}$ The male predominance observed in the present study is concordant with previous reports. ${ }^{1,18}$ This supports the widely held view that female hormones may confer a protective role against aneurysms. A pertinent observation of the present study is that the majority of superficial femoral artery aneurysms occur in younger age groups in whom circulating estrogens may still be high.

\section{Conclusion}

Femoro-popliteal aneurysms constitute less than $40 \%$ of the peripheral aneurysms and the femoral artery is the commonest site. They occur predominantly in males below 50 years and are associated mainly with trauma, and atherosclerosis. Prevalence, site and age distribution of these aneurysms in the Kenyan population differ from those described in studies of Caucasian populations.

\section{Acknowledgements}

To Kenyatta National Hospital registry staff, for availing organized records, and Catherine Chinga for typing the manuscript. 


\section{References}

1. Diwan A, Sarkar R, Stanley JC, Zelenock GB, Wakefield TW. Incidence of femoral and popliteal artery aneurysms in patients with abdominal aortic aneurysms. I Vasc Surg. 2000;31:863-9.

2. Motoki AH, Girardi AR, Ogata BR, et al. Trombose aguda de aneurisma de artéria femoral isolado: relato de caso. J Vasc Bras. 2008;7:376-9.

3. Kitchen ND. Racial distribution of aneurysms in Zimbabwe.J R Soc Med. 1989;82:136-8.

4. Robbs JV. Atherosclerotic peripheral arterial disease in blacks: an established problem. S Afr Med J. 1985;67:797-801.

5. Moini M, Rasouli MR, Rayatzadeh H, Sheikholeslami. Management of femoral artery pseudo-aneurysms in Iran: a single centre report of 50 cases. Acta Chir Belg. 2008;108:226-30.

6. Ouriel K, Shortell CK. Popliteal and femoral aneurysms. In: Rutherford RB, editor. Vascular surgery, 5th ed. Philadelphia: WB Saunders; 1995. p. 1103-12.

7. Rigdon EE, Monajjem N. Aneurysms of superficial femoral artery: a report of two cases and review of literature. J Vasc Surg. 1992;16:790-3.

8. Hamish M, Lockwood A, Cosgrove C, Walker AJ, Wilkins D, Ashley S. Management of popliteal artery aneurysms. ANZ I Surg. 2006;76:912-5.

9. Thompson MM, Bell PR. ABC of arterial and venous disease. Arterial aneurysms. BMJ 2000;320:1193-6.

10. Savolainen H, Widmer MK, Heller G, Gerber M, Carrel TP, Schmidli J. Common femoral artery: unknown aneurysms. Scan J Surg. 2003;92:203-5.

11. MacSweeney ST, Skidmore C, Turner RJ, et al. Unravelling the familial tendency to aneurysmal disease: popliteal aneurysm, hypertension and fibrillin genotype. Eur J Vasc Endovasc Surg. 1996;12:162-6.

12. Hashimoto W, Yamada T, Matsumaru I. Popliteal artery aneurysms and popliteal phymas. Ann Thorac Cardiovas Surg. 2009;15:64-7.
13. Dighe $\mathrm{S}$, Thomas P. Ruptured superficial femoral artery aneurysms treated by simple ligation. Singapore Med J. 2008;49:e151-2.

14. Corriere MA, Guzman RJ. True and false aneurysms of the femoral artery. Semin Vasc Surg. 2005;18:216-23.

15. Darbari A, Tandon S, Chandra G, Dwivedi SK, Kumar A, Gupta A. Post-traumatic peripheral arterial pseudoaneurysms: our experience. Ind J Thorac cardiovasc Surg. 2006;22:182-7.

16. Sharma NK, Chin KF, Modgill VK. Pseudoaneurysms of the femoral artery: recommendation for method of repair. J R Coll Surg Edinb. 2001:46:195-7.

17. Levi N, Schroeder TV. Arteriosclerotic femoral artery aneurysms. A short review. J Cardiovasc Surg (Torino). 1997;38:335-8.

18. Ravn H, Bergqvist D, Björck $M$. Nationwide study of the outcome of popliteal artery aneurysms treated surgically. Br J Surg. 2007;94:970-7.

19. Galindo CC, Lima CA, Cardoso JE, Galindo FG, Costa VS, Penha FM. Aneurisma aterosclerótico idolado da artéria femoral superficial: relato de caso. J Vasc Bras. 2003;2:145-7.

Correspondence:
Julius Ogeng'o
Department of Human Anatomy, University of Nairobi
PO Box $00100-30197-$ Nairobi, Kenya
Tel.: $(254$ 20)442368
E-mail: jogengo@uonbi.ac.ke
Author contributions:
Conception and design: JAO
Analysis and interpretation: BOO
Data collection: BOO
Writing the article: JAO
Critical revision of the article: BOO
Final approval of the article*: JAO, BOO
Statistical analysis: BOO
Overall responsibility: JAO
Obtained funding: N/A
All authors have read and approved the final version of the article submitted
to J Vasc Bras.

